Ks. Tadeusz Kasabuła

Uniwersytet w Białymstoku

Katedra Teologii Katolickiej

tel. +48 857457090

e-mail: t.kasabula@skrzynka.pl

\title{
Chryścijanskaja Dumka w publicystyce białoruskich chrześcijańskich demokratów
}

Słowa kluczowe: publicystyka, chrześcijańscy demokraci, „Chryścijanskaja Dumka”

\section{Wstęp}

Okres dwudziestolecia międzywojennego to czas eksplozji czasopiśmiennictwa kościelnego. Słowo drukowane stało się ważnym czynnikiem komunikacji także wewnątrz poszczególnych diecezji dawnego zaboru rosyjskiego, z czasem okazując się niezastąpionym elementem działalności duszpasterskiej [Ziółkowski 1986, 137, Kraśnicki 1991, 227]. Świadczy o tym duża liczba czasopism, wychodzących w tym czasie $\mathrm{w}$ języku polskim na terenie diecezji a od 1925 r. archidiecezji wileńskiej. W opublikowanym w 1981 r. zestawieniu katolickich czasopism religijnych w Polsce za okres 1918-1944 odnotowano istnienie około 60 tytułów. Miały one niezwykle zróżnicowany profil i różny zakres oddziaływania. Na ów intensywny rozwój czasopiśmiennictwa kościelnego złożyło się kilka czynników, spośród których na odnotowanie zasługuje fakt dokonanej przez Piusa XI nowej cyrkumskrypcji diecezji i prowincji kościelnych w Polsce. Mocą bulli Vixdum Poloniae Unitas z 28 października 1925 r., realizując postanowienia konkordatowe Papież ustanowił m.in. metropolię wileńską, określił jej ustrój i organizację. W skład nowej prowincji kościelnej weszły obok podniesionej do rangi archidiecezji dawnej 
diecezji wileńskiej diecezje sufraganalne: łomżyńska i pińska [Kumor 1971, 319-322]. Tym sposobem Wilno stało się ważnym, samodzielnym centrum życia kościelnego.

Nowo powstała archidiecezja pod względem terytorialnym była największą jednostką administracji kościelnej w Polsce międzywojennej. Obejmowała całe województwo wileńskie, część białostockiego i nowogródzkiego, ogółem $53860 \mathrm{~km}^{2}$. Ludność zamieszkująca to terytorium pod względem wyznaniowym i narodowościowym stanowiła dość urozmaiconą mozaikę. Według danych z 1939 r. najliczniejszą grupę wyznaniową w liczbie 1485484 osób stanowili katolicy obrządku rzymskokatolickiego. Wyznawców pozostałych wyznań i religii było około 1000000 . W większości byli to prawosławni i wyznawcy judaizmu. Zdecydowaną mniejszość stanowili staroobrzędowcy, muzułmanie, karaimi i ewangelicy. Terytorium archidiecezji zamieszkiwali w tym czasie, oprócz Polaków, także Litwini, Białorusini, Żydzi, Rosjanie, Tatarzy [Catalogus ecclesiarum... 1939].

Środowiskiem do niedawna mało rozpoznanym i słabo w historiografii reprezentowanym była mniejszość białoruska wyznania katolickiego. Na jej istnienie i aktywność w Polsce międzywojennej nie zwracano szczególnej uwagi, zatem i w literaturze problematykę tę poruszano jedynie ubocznie, mianowicie przy okazji badań nad mniejszością białoruską w Drugiej Rzeczypospolitej w ogóle, przy czym w badaniach koncentrowano się głównie na białoruskiej lewicy rewolucyjnej. Stąd też utrwalony jeszcze w okresie międzywojennym wizerunek Białorusina-komunisty ukształtował na długi czas obraz życia społecznego, politycznego i religijnego białoruskiej mniejszości narodowej. Obraz to zniekształcony i niepełny, co w swych badaniach udowodniła Małgorzata Moroz. Wyniki swych naukowych dociekań zawarła w kilku artykułach [Moroz 1993, 45-52; 1997, 48-61], poprzedzających wydanie niezwykle wartościowego dla poznania aspiracji narodowościowych, społecznych i religijnych białoruskich katolików opracowania pt.: „Krynica”. Ideologia i przywódcy białoruskiego katolicyzmu”. Autorka, ustosunkowując się krytycznie do funkcjonujących stereotypów i prezentując nowy punkt widzenia na sprawy mniejszości białoruskiej ustawiła badania nad tą problematyką w nowej, szerszej perspektywie. Z braku dostatecznej archiwalnej bazy źródłowej M. Moroz oparła się głównie na prasie białoruskiej, co kazało jej zweryfikować wiele z dotychczasowych ustaleń i pozwoliło na stwierdzenie, iż jakkolwiek „trudno byłoby Białorusinom równać się w zasięgu ruchu wydawniczego z pozostałymi mniejszościami narodowymi", to jednak wartym odnotowania jest fakt, że w samym tylko Wilnie w roku 1927 legalnie wychodziło 20 tytułów, w roku 1930 - 14, w 1932 - 18, w 1933 - 13, w 1934 i 1935 - 15 [Moroz 2001, 13]. 
Każde z tych pism posiada własną historię, przechodziło zmienne koleje losu, posiadało okresy wzrostu, kryzysu i nieraz całkowitego upadku. Dziejów tych nie da się objąć jednym krótkim spojrzeniem. Każde z nich dopomina się osobnych badań i opracowań, bo tylko w ten sposób można w sposób systematyczny odtworzyć ich nieraz skomplikowane, a zarazem interesujące dzieje. Opracowanie niniejsze nie rości sobie prawa, by być choćby próbą monografii jednego z nich. Bynajmniej. Zamysłem Autora jest natomiast próba zaprezentowania periodyku Chryścijanskaja Dumka i jego dziejów w okresie międzywojennym na tle całokształtu białoruskiej publicystyki chadeckiej, pisma o profilu religijno-społecznym, adresowanego do katolickiej części mniejszości białoruskiej w Drugiej Rzeczypospolitej. By zapoznać czytelnika ze środowiskiem w jakim powstało i było redagowane czasopismo należało dać garść podstawowych informacji biograficznych o ludziach je tworzących i nadających mu specyficzny, niepowtarzalny charakter forum publicystycznego, zaspokajającego potrzeby tych spośród białoruskich katolików, którzy stroniąc od polityki sensu stricto, w prasie szukali treści religijnych i informacji poruszających bliską im problematykę społeczną.

\section{Powstanie pisma}

Czasopismo Chryścijanskaja Dumka wyodrębniło się z periodyku Krynica - Biełaruskaja Krynica, głównego organu prasowego Białoruskiej Chrześcijańskiej Demokracji. Biełaruskaja Krynica było pismem adresowanym w zasadzie już od początku swego istnienia do białoruskich włościan. Miało charakter pisemka religijno-społecznego, z którego grupa działaczy białoruskiej inteligencji katolickiej próbowała stworzyć czasopismo społeczno-polityczne na skalę ogólnobiałoruską. W wyniku trwającej kilkanaście lat ewolucji pisma, w latach trzydziestych stało się ono organem prasowym partii politycznej o nazwie Białoruskie Zjednoczenie Narodowe [Moroz 2001, 212].

Ponieważ Biełaruskaja Krynica, jako organ polityczny siłą rzeczy poczęła kłaść nacisk na sprawy społeczne i polityczne, jedynie ubocznie dotykając problematyki religijnej, pojawiła się inicjatywa powołania do życia pisma, poruszającego głównie sprawy religijne katolickiej mniejszości białoruskiej. Przeglądając roczniki Biełaruskiej Krynicy, daje się zauważyć, że problematyka religijna powoli zaczyna w niej zanikać od roku 1928, czyli od chwili ukazania się pierwszych numerów Chryścijanskiej Dumki .

1 Wskazuje na to wyraźnie zawartość Bielaruskaj Krynicy z lat 1926-1929. 
Potrzebę takiego czasopisma odczuwało się już od dawna. Zapotrzebowanie na treści ściśle religijne znać w wypowiedziach czytelników Chryścijanskiej Dumki już u początków jej istnienia. Atmosferę oczekiwania na tego rodzaju pismo oddaje wypowiedź, zamieszczona w jednym z pierwszych jego numerów. „Przeczytawszy w gazetach, że ma wychodzić Chryścijanskaja Dumka, bardzo się ucieszyłem. Jestem zadowolony, że będzie u nas jedna białoruska gazeta i nie polityczna. Szczerze przyznaję się, że polityki mamy już dosyć i chcielibyśmy mieć drukowane słowo, które czytając, pozwalałoby duszy odpoczywać" - pisał na łamach pisma jeden z jego anonimowych czytelników [Rady z Dumki, 5]. Nic zatem dziwnego, że w białoruskich kręgach kościelnych ukazanie się chrześcijańskiego, katolickiego czasopisma spotkało się w dużą aprobatą. Inicjatywa ta wychodziła zatem naprzeciw aspiracjom katolickich środowisk białoruskich i przyjęta została z niemałym entuzjazmem [Z wydawieckaj niwy]. W rzeczywistości Chryścijańskaja Dumka dość szybko stała się pismem o charakterze religijno-społecznym, przypominającym periodyk Krynica w początkowym stadium jego rozwoju.

Podobnie jak Krynica i Biełaruskaja Krynica, Chryścijanskaja Dumka była wydawana w języku białoruskim i drukowana dostosowaną do wymogów języka białoruskiego czcionką łacińską, tzw. łacinką. Wydawcą Chryścijanskiej Dumki było powołane do życia dzięki staraniom księży Adama Stankiewicza, Wincentego Godlewskiego oraz dr. Bolesława Grabińskiego, stowarzyszenie pod nazwą Białoruskie Wydawnictwo Katolickie, wciągnięte do rejestru organizacji społecznych 19 lutego 1929 r. Zaistnienie tej jednostki otwierało nowe pole i stwarzało nowe możliwości dla działalności aktywistów białoruskiej chadecji. W statucie stowarzyszenia jako jego cele wymieniono: wydawanie czasopism, książek i innych druków, zakładanie księgarń, organizowanie kwest, odczytów, spektakli teatralnych. Stowarzyszenie swym zasięgiem miało objąć województwa wileńskie, nowogródzkie, białostockie i poleskie. W początkowym okresie Białoruskie Wydawnictwo Katolickie miało przede wszystkim zająć się wydawaniem Chryścijanskiej Dumki. Problemy pojawiły się już na początku działalności stowarzyszenia i związane były z fatalną sytuacją finansową drukującej czasopismo Białoruskiej Drukarni im. Franciszka Skoryny, spowodowaną spadkiem zamówień po publikacji rozporządzenia arcybiskupa Romualda Jałbrzykowskiego z grudnia 1928 r. o zakazie przynależności duchownych katolickich do stowarzyszenia Białoruska Chrześcijańska Demokracja i sympatyzowania z tym ruchem, tudzież zabraniającego wiernym prenumerowania, czytania i rozpowszechniania Bietaruskiej Krynicy, co oznaczało faktyczną zapaść w działalności wileńskiego środowiska białoruskich chadeków [Szot 2002, 65]. By ratować upadające 
wydawnictwo księża Stankiewicz i Jaremicz zdecydowali się na ryzykowny krok, zawierając umowę z Białoruskim Włościańsko-Robotniczym Klubem Poselskim „Zmachańnia” przewidującą, w zamian za pomoc finansową, drukowanie radykalnej gazety Sviet [Moroz 2001, 177-178]. Trudno nie przyznać racji M. Moroz, iż: ,zgoda na drukowanie organu prasowego tak radykalnego ugrupowania jakim było „Zmachańnie”, podejrzewanego o ścisłe związki z KPZB [Komunistyczna Partia Zachodniej Białorusi - T.K.], była niemal aktem desperacji, zwłaszcza, że na białoruskich działaczach chadeckich ciążył zarzut [wyartykułowany w rozporządzeniu z grudnia 1928 r. - T.K.] indyferentyzmu religijnego i bolszewizmu" [Moroz 2001, 178]. Ta decyzja źle usposobiła zarówno polskie władze państwowe, jak też środowiska kościelne, także do redakcji Chryścijanskiej Dumki i to już u początku istnienia czasopisma.

Życzeniem redakcji było, by Chryścijanskaja Dumka ukazywała się regularnie, najlepiej co tydzień [ChD, 1(1998)]. W rzeczywistości tego idealnego stanu nigdy nie udało się utrzymać przez czas dłuższy. Potencjał finansowy redakcji, możliwości wydawnictwa i inne pojawiające się okoliczności, także natury politycznej, czyniły z Chryścijanskiej Dumki siłą rzeczy czasopismo o charakterze periodyku. Wychodziło ono nieregularnie, choć w okresie największej prosperity, w połowie lat trzydziestych, utrzymywało się przez dłuższy czas jako dwutygodnik, co w 1937 r. dało redakcji tytuł do umieszczenia na stronicy tytułowej notki Białoruski Katolicki Dwutygodnik. Faktycznie czasopismo nawet w okresie jednego roku ukazywało się jako dwutygodnik, miesięcznik, czasami łączono numery w dwumiesięcznik. W latach 1938-1939 Chryścijanskaja Dumka zaczęła ukazywać się częściej, utrzymując przez dłuższy czas średnio liczbę trzech numerów $\mathrm{w}$ miesiącu.

\section{Komitet redakcyjny}

\section{A. Redaktorzy naczelni}

Twórcą i pierwszym redaktorem naczelnym czasopisma Chryścijanskaja Dumka był ks. Adam Stankiewicz urodzony 24 grudnia 1891 r. (według starego stylu) we wsi Orlaniaty w powiecie oszmiańskim, w województwie wileńskim. Pochodził z rodziny chłopskiej Białorusinów-katolików. Wieś rodzinna pod względem wyznaniowym była jednorodna. Z wyjątkiem jednej osoby prawosławnej wszyscy byli katolikami [Шутовіч 1940, 13]. Przodkowie ks. Stankiewicza należeli do Kościoła katolickiego obrządku wschod- 
niego. Po kasacie unii część z nich przyjęła prawosławie, część przeszła na katolicyzm w obrządku łacińskim. Ksiądz Jan Szutowicz pisząc o krewnych ks. Stankiewicza zaznaczył, że pomimo różnicy wyznań, nigdy w rodzinie nie dochodziło na tym tle do konfliktów. Podczas rodzinnych uroczystości (chrzest, ślub, pogrzeb) wszyscy brali udział w nabożeństwach bez względu na to, czy odbywały się one w cerkwi, czy w kościele [Шутовіч 1940, 13].

Rodzice rozpoznawszy zdolności syna i jego pęd do wiedzy zdecydowali się na dalsze jego kształcenie. W związku z tym powstało pytanie, dokąd go skierować? Szkoły w rodzinnej wsi nie było. Najbliższe znajdowały się w Borunach i Krewie. Brano pod uwagę szkołę w Borunach, którą do kasaty unii prowadzili katoliccy bazylianie, a obecnie znajdowała się tam prawosławna szkoła parafialna i seminarium nauczycielskie. Do tej szkoły, głównie z racji na stosunkowo niewielką jej odległość od domu rodzinnego, wysłano młodego Adama. Po oddaniu syna do szkoły ojciec wrócił do domu z poczuciem dobrze spełnionego obowiązku, natomiast dla syna rozpoczęła się prawdziwa gehenna. Już w pierwszym dniu nauki, gdy przeżegnał się po katolicku, został przez nauczyciela spoliczkowany. W Borunach po raz pierwszy zrodziła się w nim niechęć i lęk przed „ruską wiarą”. Po raz pierwszy też uświadomił sobie swą odmienność płynącą z faktu, iż jest on „polskiej wiary” [Гарошка 1999, 403-404].

W następnym roku ojciec oddał syna do szkoły w Holszanach. Była to szkoła państwowa, w której wszystkie zajęcia, a więc i lekcje religii katolickiej, prowadzono po rosyjsku. Mimo to młody Adam poczuł się tu bardzo dobrze. „Szybko się znalazł w towarzystwie kolegów, a także w zakrystii i przy ołtarzu jako ministrant". W Holszanach przebywał w latach 1902-1904. Po złożeniu końcowych egzaminów rodzice skierowali go do szkoły miejskiej w Oszmianie. Spędził tam cztery lata i jako uczeń wziął udział w strajkach szkolnych wymierzonych w politykę rusyfikacyjną caratu. Wówczas to poczęło się w nim krystalizować poczucie przynależności narodowej. Według jego własnych wspomnień, pomimo katolickiego wyznania uświadomił sobie, że Polakiem nie jest. Szkołę w Oszmianie ukończył w 1908 r. w wieku 18 lat [Гарошка 1999, 404].

Lektura pism Franciszka Bohuszewicza (Dudka bietaruskaja i Smyk biełaruski) oraz białoruskie publikacje historyczne pozwoliły mu wyrobić pogląd na temat swojej etniczności. Faktem jest, że wstępując w 1910 r. do seminarium duchownego w Wilnie czuł się już w pełni świadomym Białorusinem, czemu po roku pobytu w seminarium dał wyraz deklarując się oficjalnie jako Białorusin. Nie było to dla nikogo zaskoczeniem, gdyż alumn Stankiewicz już wcześniej nie krył przed władzami seminaryjnymi swej świadomości co do przynależności narodowej. Nie taił też swoich poglądów, po- 
dejmując odważne dyskusje w gronie alumnów, m.in. na temat możliwości wprowadzenia języka białoruskiego do nabożeństw, potrzeby wydawnictw białoruskich, czy zgodności aspiracji emancypacyjnych mniejszości białoruskiej z katolicką nauką społeczną [Moroz 2001, 41].

Już u początków pobytu w seminarium duchownym Stankiewicz znalazł się wśród inicjatorów powołania do życia Koła Białoruskiego. Było to przedsięwzięcie dość ryzykowne, jako że władze seminaryjne z niechęcią odnosiły się do manifestowania innej, niż polska, narodowości. Niemniej ówczesny rektor wyraził zgodę na nadanie kołu form organizacyjnych i na założenie przy nim białoruskiej biblioteczki. Zastrzegł jedynie, by kółko nie niosło szkody Kościołowi. Po otrzymaniu zapewnienia, że „Białorusini katolicy chcą większej korzyści dla katolicyzmu w swoim zorganizowanym odrodzeniu” władze seminaryjne nie stawiały przeszkód dla działalności Koła. Do białoruskiego kółka seminaryjnego należeli alumni, późniejsi działacze białoruskiej chadecji: Józef Reszeć, Michał Szałkiewicz, Franciszek Aleszkiewicz, Andrzej Cikota, Aleksander Augustynowicz, W. Łuksza, K. Stepowicz, J. Sławecki, J. Daszuta, M. Boryk, J. Lewkowicz, W. Romanowski, J. Dauksza i inni [Шутовіч 1940, 37].

Po zakończeniu formacji w seminarium duchownym w Wilnie ks. Stankiewicz podjął studia w Akademii Duchownej w Petersburgu. Tam też 28 grudnia 1914 r. przyjął święcenia prezbiteratu. Akademię ukończył na wiosnę 1918 r. i jesienią tego roku przybył do będącego jeszcze pod okupacją niemiecką Wilna. Stąd skierowano go do pracy duszpasterskiej w Drohiczynie n/Bugiem. Przebywał tam do sierpnia 1919 r. [Stankievič 1939, 134-137], po czym, korzystając z przychylności biskupa Jerzego Matulewicza, wrócił do Wilna z zamiarem podjęcia działalności narodowo-religijnej i kulturalno-oświatowej w środowisku białoruskich katolików [Гарбінскі 1999, 18]. Realizując ten program zainicjował wznowienie pisma „Krynica” i został jej redaktorem i wydawcą. Pracował też jako nauczyciel religii w wileńskim gimnazjum białoruskim. Aktywnie współpracował z Komitetem Pomocy Ofiarom Wojny. Od roku 1921 regularnie odprawiał nabożeństwa w języku białoruskim w kościele św. Mikołaja [Stankievič 1939, 148-149]. Nadal aktywnie działał w środowisku Białorusinów-katolików, szybko wyrastając na głównego ideologa białoruskiej chadecji. Po zamknięciu w 1925 r. redakcji Krynicy, ks. Stankiewicz został, po miesiącu przerwy w pracy redakcyjnej, formalnym redaktorem pisma będącego kontynuacją Krynicy - Biełoruskiej Krynicy. Po publikacji rozporządzenia arcybiskupa Jałbrzykowskiego w grudniu 1928 r., ks. Stankiewicz nie przestał sympatyzować z ruchem białoruskich chadeków. Czynił to w inny sposób, stając się inicjatorem powołania do życia nowego czasopisma dla katolików-Białorusinów - Chryścijanskiej Dumki, 
pisma o profilu religijno-społecznym, formalnie odcinającego się od działalności politycznej. Został też redaktorem naczelnym stworzonego przez siebie nowego organu prasowego [Moroz 2001, 132-133].

Z punktu widzenia polskich czynników państwowych i władz kościelnych działalność ks. Stankiewicza koło budzenia świadomości narodowej mniejszości białoruskiej była niewygodna, postrzegana była jako niebezpieczna dla utrzymania integralności państwa polskiego, zwłaszcza po tym, jak duchowni skupieni wokół Biełaruskiej Krynicy, w tym ks. Stankiewicz, nie zastosowali się w pełni do rozporządzenia Arcybiskupa zawartego w rozporządzeniu z $1928 \mathrm{r}$. Te i inne wydarzenia legły u podstaw decyzji o przeniesieniu w 1938 r. ks. Stankiewicza do Słonimia, co faktycznie oznaczało jego izolację od środowiska białoruskich katolików. Do Wilna wrócił dopiero na początku II wojny światowej. W warunkach okupacji niemieckiej podjął wykłady z historii Białorusi, uczył też religii w ponownie otwartym gimnazjum białoruskim oraz w białoruskim seminarium nauczycielskim. Po wkroczeniu na Wileńszczyznę w 1944 r. Armii Czerwonej ks. Stankiewicz został 7 grudnia t.r. aresztowany i osadzony w więzieniu NKWD na Łukiszkach. Zwolniono go po kilku dniach. Musiał się ukrywać, stąd trudno dokładnie określić, gdzie przebywał i co robił przez najbliższe pięć lat. Faktem jest, że 13 kwietnia 1949 r. został po raz drugi aresztowany i skazany na 25 lat łagru w Tajszecie, gdzie 4 grudnia t.r. zmarł. Pochowany został na cmentarzu w pobliżu wsi Szawczenka w rejonie tajszeckim². Wiktor Sikora, który w tym czasie również był więziony w Tajszecie, złożył relację o śmierci i pogrzebie ks. Stankiewicza. Najokrutniejszy moment, który pamięta to ten, gdy - jak mówi - „przyszli Litwini, aby prosić o wodę, gdyż w ich baraku umierał ksiądz". Kiedy dowiedział się, że chodzi o ks. Stankiewicza, ruszył natychmiast do wskazanego baraku, ale ksiądz już nie żył. Według regulaminu obozowego ciało zmarłego, zanim zostało pogrzebane, musiało zostać przewiezione do kostnicy, by służba obozowa mogła upewnić się co do rzeczywistego zgonu więźnia. Strażnicy obozowi obawiali się, by więzień udając martwego, nie wydostał się poza obóz. Pogrzebem księdza zajął się Sikora. Przewiózł saniami ciało zmarłego do prowizorycznej kostnicy, gdzie czekał już dyżurny „rzeźnik”, jak nazywano strażnika obozu stwierdzającego zgon więźnia. Tak zwaną „kichą”, czyli przedmiotem, którym rybacy w zimie wyrąbują przeręble, uderzył w pierś zmarłego, po czym inny począł okładać ciało zmarłego pałką, masakrując jego głowę [Ёрш 1999].

2 Białoruskie Państwowe Muzeum Historii Religii w Grodnie, pismo z dnia 25 IX 1990 r. informujące o śmierci ks. Adama Stankiewicza (bez sygnatury). 
Oficjalna notka o śmierci ks. Stankiewicza znajduje się obecnie w Białoruskim Państwowym Muzeum Historii Religii w Grodnie. Według tego dokumentu ks. Stankiewicz zmarł śmiercią naturalną, a powodem zgonu miała być choroba serca ${ }^{3}$.

Tymczasowym redaktorem naczelnym Chryścijanskiej Dumki od roku 1938 był Jan Poźniak. Urodził się 19 lutego 1895 r. w miasteczku Subotniki w powiecie lidzkim w guberni grodzieńskiej w chłopskiej rodzinie katolickiej. Posiadał wykształcenie średnie, ukończył też szkołę muzyczną, co pozwoliło mu objąć posadę organisty, najpierw w Ławaryszkach, potem przy kościele św. Jana w Wilnie [Гарбінскі, 136-137]. W latach 1913-1915 współredagował jedno z pierwszych katolickich czasopism białoruskich Biełarus. Ponadto współpracował z pismem „Biełaruskaja Krynica", by w latach 1928-1936 zostać jego redaktorem naczelnym. Jednocześnie współredagował pismo Chryścijanskaja Dumka. Po rozwiązaniu „Biełaruskiej Krynicy" związał się na stałe z redakcją Chryścijanskiej Dumki, by od grudnia 1938 r. pełnić funkcje jej redaktora naczelnego. W końcu 1939 r. został aresztowany przez NKWD i osadzony w więzieniu w Mołodecznie. Data, miejsce i okoliczności śmierci Jana Poźniaka pozostają do dziś nieznane [Гарбінскі, 137].

\section{B. Współpracownicy}

Chryścijanskaja Dumka nie zatrudniała stałych dziennikarzy. Redakcja utrzymywała natomiast stałe kontakty z autorami, zarówno księżmi, jak też świeckimi, którzy w miarę regularnie nadsyłali swoje teksty. Jednym z najczęściej pojawiających się na łamach „Chryścijanskiej Dumki” publicystów był ks. Józef Reszeć, wykładowca filozofii i apologetyki w diecezjalnym seminarium duchownym w Wilnie, profesor patrologii na USB i katecheta $\mathrm{w}$ gimnazjum białoruskim w Wilnie. W roku 1938 wyjechał do USA, gdzie wstąpił do zakonu oo. benedyktynów. Zmarł 15 lutego 1958 r. [Choruży 1997, 158-160].

Z redakcją Chryścijanskiej Dumki ściśle współpracował ks. Piotr Tatarynowicz. Przed powstaniem pisma pisywał do „Krynicy” i „Biełaruskiej Krynicy". Publikował również w unickim białoruskim czasopiśmie Да злyчэння. W roku 1944 wyemigrował do Niemiec, następnie wyjechał do Rzymu, gdzie w latach 1945-1950 studiował w Papieskim Instytucie Orientalnym, wieńcząc studia stopniem doktora. Od roku 1950 wydawał białoruskie

3 Białoruskie Państwowe Muzeum Historii Religii w Grodnie, pismo z dnia 25 IX 1990 r. informujące o śmierci ks. Adama Stankiewicza (bez sygnatury). 
katolickie czasopismo Źnič. Głównie dzięki jego zaangażowaniu powstała sekcja białoruska Radia Watykańskiego. Podjął też obowiązki dyrektora katolickiego duszpasterstwa wśród emigracji białoruskiej. Zmarł 3 września 1978 r. w Rzymie [Сіповіч 1999b, 437-442].

Środowisko Chryścijanskiej Dumki współtworzył kolega ks. Stankiewicza z saminaryjnej ławy ks. Wiktor Szutowicz. Po powrocie z USA, gdzie przebywał w latach 1929-1932 oddał się pracy publicystycznej i duszpasterskiej, między innymi był proboszczem katedry w Mińsku. W grudniu 1945 r. został aresztowany. Skazany na zesłanie przebywał w Komi aż do roku 1956. Ostatnie lata życia spędził jako proboszcz parafii w Borysowie, gdzie 1 marca 1960 r. zmarł. Jego doczesne szczątki spoczęły na miejscowym cmentarzu [Гарбінскі, 220-221].

Mówiąc o autorach stale współpracujących z redakcją Chryścijanskiej Dumki nie sposób pominąć Dominika Aniśko, najbardziej aktywnego na jej łamach autora świeckiego. Z pismem współpracował przez wszystkie lata jego istnienia w okresie międzywojennym. Po II wojnie światowej, w 1947 r., wyemigrował do Wielkiej Brytanii, gdzie co jakiś czas zamieszczał swe publikacje w emigracyjnych czasopismach polskich i białoruskich. Żywot zakończył w Londynie 28 grudnia 1971 r. Tam też, na cmentarzu św. Pankracego, został pochowany [Гарбінскі, 7, Аніська 1999, 258-263].

Autorem wielu tekstów Chryścijanskiej Dumki był marianin i proboszcz z Drui oraz magister tamtejszego nowicjatu, katecheta i nauczyciel łaciny w drujskim gimnazjum, ks. Józef Hermanowicz. W 1932 r. pod naciskiem władz polskich został przeniesiony do misji mariańskiej w Harbinie, gdzie pracował jako wychowawca w męskim gimnazjum św. Mikołaja. Aresztowany w 1948 r. przez władze chińskie, niezwłocznie został przekazany NKWD. Osadzono go w areszcie śledczym w mieście Czita, po czym zesłano do łagru w Tajszecie [Bukowski 2001, 103-107]. Na zesłaniu przebywał do 1955 r., po czym, po zwolnieniu z łagru, zmuszono go do wyjazdu do Polski. W końcu 1959 r. udał się do Włoch, a później do Wielkiej Brytanii, gdzie 26 grudnia 1978 r. zmarł. Pochowany został w Londynie na cmentarzu św. Pankracego [Сіповіч 1999a, 289-296].

\section{Nakład i odbiorcy}

Redakcja Chryścijanskiej Dumki w żadnym z numerów nie zamieściła informacji o wysokości nakładu, stąd trudno ustalić precyzyjnie liczbę drukowanych egzemplarzy konkretnego numeru. Pismo utrzymywało się wyłącznie z dobrowolnych ofiar i opłat za prenumeratę. Prenumeratorzy zaś 
nie zawsze byli w stanie wnieść w terminie, bądź w ogóle opłacić prenumeratę. Osoby lub instytucje, których nie stać było na uiszczenie opłaty za stałą prenumeratę nierzadko, miast gotówki, przysyłali artykuły do publikacji. W czasopiśmie była więc stała rubryka Skrzynka pocztowa, w której redakcja $\mathrm{w}$ kilku słowach odpowiadała na listy oraz podawała informację, kto i jakiej wysokości kwoty nadsyłał. Często wysyłano egzemplarze pilotażowe czasopisma po to, by wierni, zanim podejmą decyzję o prenumeracie, mogli zapoznać się z charakterem proponowanych treści. Na podstawie zawartości tej rubryki można w przybliżeniu określić jeżeli nie wprost nakład pisma, to przynajmniej liczbę stałych prenumeratorów w poszczególnych latach.

\section{Przybliżona liczba stałych prenumeratorów czasopisma} „Chryścijanskaja Dumka” w latach 1928-1939

\begin{tabular}{|c|c|c|}
\hline Rocznik & Duchowni & Świeccy \\
\hline 1928 & 98 & 95 \\
1929 & 58 & 83 \\
1930 & 24 & 38 \\
1932 & brak danych & brak danych \\
1933 & 14 & 52 \\
1934 & 25 & 104 \\
1935 & 35 & 74 \\
1936 & 14 & 42 \\
1937 & 48 & 260 \\
1938 & 8 & 124 \\
1939 & brak danych & 8 \\
\hline
\end{tabular}

Przeprowadzone przez Jana Traczuka z Grodna w latach dziewięćdziesiątych ubiegłego stulecia badania i dokonane przezeń obliczenia pozwalają na przybliżone określenie nakładu wielu białoruskich czasopism, w tym także "Chryścijanskiej Dumki”. W swych dociekaniach przyjrzał się parafiom o dużej liczbie Białorusinów-katolików, czyli tych placówek duszpasterskich, co do których miał pewność, że były zainteresowane prenumeratą „Chryścijanskiej Dumki”. Wyniki, jakie uzyskał pozwalają szacować, że w okresie największej prosperity pismo to wychodziło nawet $\mathrm{w}$ nakładzie sięgającym 1000 egzemplarzy. Rozliczne przeszkody, m.in. problemy finansowe wydawnictwa, ograniczenia administracyjne, a także kłopoty finansowe samej redakcji, kazały zmniejszyć nakład nawet do 600 egzemplarzy. W sumie 
średni nakład czasopisma oscylował w granicach 600-800 egzemplarzy [Traczuk 1992, 185-373].

Czasopismo było skierowane głównie do katolików narodowości białoruskiej szukających treści religijnych i interesujących się kwestią społeczną, ludzi stojących na uboczu wielkiej polityki, którym nie po drodze było ze środowiskiem realizującym radykalizujący się coraz bardziej program BieŁaruskiej Krynicy. Nie oznaczało to bynajmniej, że redakcja odżegnywała się od narodowościowych aspiracji i dążeń emancypacyjnych białoruskiej mniejszości. Nic podobnego. Znaczna część prenumeratorów pisma czytała i Chryścijanska Dumkę i Bietaruska Krynice, w jednym i drugim czasopiśmie odnajdując treści im bliskie i nawzajem się uzupełniające. W zamyśle redakcji periodyk nie powinien zamykać się w wąskich granicach określonych narodowością i wyznaniem. Życzeniem twórców pisma było, by trafiło ono także na drugą stronę barykady, by również adwersarzom programowym pokazać, iż można godzić postulaty o charakterze narodowym, graniczące nieraz z postawami nacjonalistycznymi, z katolicka nauką społeczną. Kwestią otwartą pozostaje pytanie, czy owo przekonanie istotnie daje się przełożyć na rzeczywistość, a jeżeli już, to w jakich stopniu i do jakich granic. Niemniej redakcja otwierała łamy czasopisma na dyskusję i nie stroniła od tematów drażliwych, trudnych, rozbudzających emocje. Stanowi to niewątpliwie o oryginalności, wyjątkowości i wysokiej wartości pisma. Ów pluralizm poglądowy Chryścijanskiej Dumki znalazł swe odzwierciedlenie w programowym artykule D. Aniśko, gdzie autor wskazując na przyszłe szerokie grono odbiorców pisał między innymi: „Leć-że «Dumka», leć do naszych braci wioskowych, pod ich słomiane dachy (...). Leć-że, «Dumka» i na biurka działaczy białoruskich! Leć do tych wszystkich, co cierpią za miliony, dopomóż im znaleźć lekarstwo na rany swego narodu. Leć na plebanię każdego księdza, co postawiony do pracy wśród białoruskiego narodu, bądź to Białorusin, Polak czy Litwin (...). Leć wreszcie do wszystkich-wszystkich naszych braci Białorusinów, żeby być im pociechą w smutku, w niedoli, żeby dzielić razem z nimi i godziny wesołe, żeby być wiernym przyjacielem dla każdego we wszystkich chwilach ich życia" [Aniśko 1928, 4]. Już forma tego apelu określa potencjalny zasadniczy krąg odbiorców. Bezpośrednimi adresatami Chryścijanskiej Dumki na pewno nie było rozintelektualizowane środowisko białoruskich działaczy politycznych.

Czasopismo widziało w kręgu swych czytelników także Białorusinów wyznawców prawosławia. Wydaje się, że istotnie, przynajmniej jakaś część prawosławnych Białorusinów nie stroniła od katolickiej prasy białoruskiej, oddając się także lekturze Chryścijanskiej Dumki. Co przyciągało tę kategorię czytelników? Odpowiedź zdaje się tkwić w korespondencji jednego 
z czytelników, właśnie prawosławnego Białorusina, który w liście do redakcji pisał: „ "Chryścijanskaja Dumka» nie pluła w duszę prawosławnego Białorusina, nie znieważała jego religijnego poczucia, a przytulała pod swoje braterskie skrzydło, gdzie wychowuje się ta święta «łączność», o którą wy i my modlimy się" [Listy z wioski, 7].

\section{Szata graficzna i zawartość czasopisma}

Na przestrzeni 11 lat istnienia Chryścijanskiej Dumki strona formalna nie odznaczała się stałością, aczkolwiek da się zauważyć pewną regularność, szczególnie na przestrzeni pewnego okresu. Szata graficzna czasopisma w zasadzie jest prosta, chociaż w początkowych latach jego istnienia stosowano dość bogato ornamentykę. Okładka wykonana była z papieru kolorowego, który to kolor dostosowywano do danego okresu liturgicznego, chociaż nie było to ścisłą regułą i z czasem prawidłowości tej zaniechano. W ostatnich rocznikach z tej zasady zrezygnowano zupełnie.

Na okładce pierwszego rocznika w górnej jej części na środku umieszczono rysunek obrazujący otwartą księgą Pisma św., na jej stronicach widnieją litery alfa i omega. Księge wkomponowano w motyw wschodzaccego słońca. Na tle tego rysunku usytuowano tytuł czasopisma ozdobiony ornamentami w kształcie kwiatów. Niżej, z prawej strony, umieszczono rysunek przedstawiający Chrystusa trzymającego w prawej ręce sierp, lewą zaś przytrzymującego na ramieniu snop zboża. W dolnej części okładki - wizerunek symbolizujący szatana podpalającego związane chwasty. Po lewej stronie, pod tytułem - cytat z ewangelii wg św. Mateusza (Mt 3, 12): „...i źbiare swaju pšanicu ŭ humno, a paśledki spale ahniom niaŭhasnym” ( „,...pszenicę zbierze do spichlerza, a plewy spali w ogniu nieugaszonym"). Cała kompozycja została ujęta w prostą, liniową ramę. W lewym rogu, nad ramką, podano rok wydania, natomiast z prawej strony - jego numer [ChD, 1 (1928)].

Drugi i trzeci rocznik co do formy graficznej są jednakowe. Okładka przedstawia wizerunek Chrystusa jako ogrodnika, troszczącego się o drzewko. Jest on umieszczony z lewej strony pod usytuowanym w górnej części okładki tytułem. Z prawej strony w ramce - rocznik i numer wydania. Nieco niżej podano streszczenie zawartości czasopisma [ChD, 2 (1929); 3 (1930)]. Do rocznika czwartego Autor nie dotarł.

W piątym roczniku bezpośrednio pod tytułem zarezerwowano, w układzie poziomym, miejsce na numer rocznika, dalej, pośrodku, miejsce na oznaczenie dokładnej daty jego wydania. Po prawej stronie umieszczono numer wydania, po lewej rysunki aniołów, na środku, w centralnym miejscu 
- cytat z ewangelii wg św. Mateusza (Mt 4, 4): „Nie adnym chlebam žywie čaławiek, ale ŭsiakim słowam, što wychodzić z wusnaŭ Božych” ( „Nie samym chlebem żyje człowiek, lecz każdym słowem, które pochodzi z ust Bożych") [ChD, 5 (1932)].

Rocznik szósty eksponuje na okładce obraz „Dobrego Pasterza” nawiązujący do fragmentu z ewangelii wg św. Jana (J 10, 14): „Ja dobry pastyr, i znaju swaich, i maje mianie znajuć” („Ja jestem dobrym pasterzem i znam moje [owce-T.K.] i moje mnie znają”) oraz słowa psalmu 32: „Bahasłaŭleny narod, katoraha Panam Bog Jahony” („Błogosławiony naród, którego Panem Bóg Jego”). Górna część okładki w stosunku do poprzedniego rocznika nie uległa zmianie [ChD, 6 (1933)].

W numerze pierwszym z roku 1934, w odróżnieniu od poprzednich z lat 1932 i 1933 r., pod tytułem zaznaczono, że jest to „Białoruskie Katolickie Czasopismo". Z prawej strony, w środku, określono miejsce wydania, a także rok periodyku i numer. Na okładce nakreślono trzy krzyże różnej wielkości oraz podano fragment z Drugiej Księgi Kronik (2 Krn 20, 20): „Wiercie ŭ Pana Boha wašaga, i biaśpiečnymi budziecie; wiercie prarokam Jaho i ŭsio-budzie pamysna” („Zaufajcie Panu, Bogu waszemu, a ostaniecie się, zaufajcie Jego prorokom, a będzie się wam dobrze powodziło") [ChD, 7 (1934)]. Wyraźnie wyróżniają się okładki czasopisma z lat 1935 i 1936. W części górnej stronicy umieszczono motywy, nawiązujące do aktualnego okresu liturgicznego, bądź wydarzeń z życia Kościoła [ChD, 8 (1935); 9 (1936)].

W następnych latach zrezygnowano $\mathrm{z}$ jakichkolwiek rysunków czy ozdób. Powodem był fakt, że czasopismo zaczęło ukazywać się trzy razy w miesiącu, czyli częściej, niż dotychczas. Zrezygnowano z zamieszczania spisu treści, który był podawany we wcześniejszych numerach. Szata graficzna stała się zatem w stosunku do poprzednich numerów o wiele skromniejsza, mniej rozbudowana i nie tak urozmaicona. Tak więc grafika stronicy tytułowej rocznika 1937 ograniczyła się jedynie do umieszczenia w górnym lewym rogu, tuż obok tytułu czasopisma, reprodukcji fotografii kaplicy Ostrobramskiej. Pod tytułem dodano jego uzupełnienie: „Białoruski Katolicki Dwutygodnik". Na dole stronicy podano: rok, numer, miejsce i dokładną datę wydania [ChD, 10 (1937)].

Roczniki z lat 1938 i 1939 co do szaty graficznej są niemal identyczne. Na stronicy tytułowej, obok tytułu, umieszczono jedynie informację określającą numer, ciągłość wydania, miejsce, dokładną datę oraz notkę, że jest to czasopismo białoruskie i że wychodzi trzy razy w miesiącu. Uderzający jest brak określenia pisma, jako katolickie [ChD, 11 (1938); 12 (1939)]. Pominięcie tej informacji nie powinno budzić zdziwienia, zważywszy na fakt, iż w piśmie 
tym, po rezygnacji ks. Stankiewicza z funkcji redaktora naczelnego, zwolna poczęła znikać z jego łam problematyka religijna. W niektórych numerach czasopisma zaznaczano, iż ma ono dodatek dla dzieci - pisemko Zorka.

Czasopismo było co do swej formy i układu treści dość zachowawcze. W numerach z 1928 roku stałymi rubrykami były: Z relihijna-kaścielnaha žyćcia (Z życia religijno-kościelnego) Chronika (Kronika), Kutok žartaŭ (Kacik żartów), Usiačyna (Rozmaitości), Paštowaja skrynka (Skrzynka pocztowa). Te rubryki pozostały w niezmienionej formie, aż do końca istnienia czasopisma. Stałą jego rubryką był „Kalendaryk” („Kalendarz”), w której podawano na najbliższy okres daty świąt i liturgicznych wspomnień świętych, tak dla katolików obrządku łacińskiego, jak i wschodniego. Najważniejsze, najbardziej eksponowane miejsce zajmowały pojedyncze, mniej lub bardziej obszerne, artykuły, bądź cykle artykułów, podejmujące najczęściej aktualne problemy religijne i społeczne. W kilku numerach czasopisma pojawiły się rozważania dotyczące Osób Trójcy Świętej, rozważanie różańca św., żywoty świętych oraz teksty o problematyce apologetycznej [ChD, 1 (1928)].

W numerach z 1929 roku opublikowano tekst Lekcyja, Ewangelija i nauka (Lekcja, Ewangelia $i$ nauka) na niedziele i święta. Tutaj też relację ze swojej podróży opublikował w artykule $Z$ Drui ŭ Charbin $(Z$ Drui do Charbinu) F. Abrantowicz. W roczniku tym wyeksponowany został artykuł ks. A. Stankiewicza Rodnaja mowa ŭ światyniach (Ojczysty język w światyniach) [ChD, 21 (1929)].

W roczniku szóstym (z 1933 r.) na pierwszej stronie każdego numeru zamieszczono teksty poruszające aktualne sprawy z życia religijnego oraz problemy Kościoła lokalnego. Publikowano też teksty czytań na niedziele i święta wraz z rozważaniem treści Ewangelii. Wyróżniającym się tekstem jest tu obszerny artykuł J. Tarasiewicza pt.: Čaławiek - šukannik Boha (Człowiek - poszukiwacz Boga) oraz tekst D. Aniśko Usio ŭ miłaści (Wszystko w miłości). Przez szereg numerów drukowano białoruski przekład książki Tomasza a Kempis Śledam za Chrystusam (O naśladowaniu Chrystusa). Od numeru trzeciego zaczęto drukować w odcinkach artykuł autora podpisującego się inicjałami K. N. na temat XXXI Międzynarodowego Kongresu Eucharystycznego [ChD, 6 (1933)].

W dziewiątym roku (1936) wydawania czasopisma Chryścijanskaja Dumka redakcja zwróciła się do czytelników z prośbą o opinię, jakich ewentualnie zmian należy dokonać w treści i układzie pisma, by było ono coraz bardziej atrakcyjne, bardziej odpowiadające duchowi czasu, by skuteczniej wychodziło naprzeciw zapotrzebowaniom czytelnika. Redakcja pół roku zbierała uwagi czytelników. Były one niezwykle zróżnicowane, mniej lub 
bardziej zasadne, niektóre wręcz zaskakujące, jak choćby te, domagające się usunięcia z czasopisma tekstów czytań mszalnych, jako niezrozumiałych. Najczęściej pojawiającym się postulatem było mało realne żądanie, by czasopismo ukazywało się w charakterze tygodnika [U čym budzie abnowa Chryścijanskaj Dumki, 1]. Pojawiały się głosy, by do współpracy w redagowaniu Chryścijanskiej Dumki włączyli się księża marianie. Propozycje te zważywszy na fakt, iż duchowni tego zgromadzenia, zwłaszcza środowisko marianów z Drui, pozostawali w niełaskach władz państwowych i kościelnych, nie miały większych widoków na realizację. Nie brakło też opinii, że pismo jest zanadto przesycone treściami religijnymi oraz by nadać mu charakter bardziej laicki, co zdaniem zgłaszających te uwagi, bardziej uatrakcyjniłoby czasopismo i powiększyło grono odbiorców. Wiele wskazuje na to, iż była to delikatna próba uaktywnienia pisma na arenie politycznej, od której redakcja, chcąc zachować dotychczasowy charakter czasopisma, stroniła. Spośród nadesłanych propozycji redakcja przychylnie ustosunkowała się do tych, które wskazywały na potrzebę większego zaangażowania społecznego czasopisma. Redakcja złożyła obietnicę, że dołoży starań, by teksty potrącające o sprawy społeczne, postrzegane w duchu nauki katolickiej, częściej gościły na łamach pisma. Stałą troską redakcji było, by czasopismo trafiało do jak najszerszego grona czytelników, także do najmłodszych. Stąd też już w następnym roczniku (1937) pojawiła się rubryka dla dzieci „Wasilki” („Bławatki”) [U čym budzie abnowa Chryścijanskaj Dumki, 1].

Zawartość pisma z roku 1937 wskazuje, iż redakcja ustosunkowała się negatywnie do propozycji bardziej radykalnych zmian $\mathrm{w}$ profilu pisma, uwzględniając częściowo i akceptując jedynie te, które mieściły się w ramach dotychczasowego charakteru pisma religijnego-społecznego. W sumie wprowadzone zmiany miały charakter bardziej kosmetyczny i w zasadzie ograniczyły się do zmiany tytułów kilku rubryk [ChD, 10 (1937)].

Ferment w łonie redakcji i współpracujących z nią autorów jednak narastał. To, jak też ogólna sytuacja radykalizującego się ruchu białoruskiej chadecji sprawiły, iż roczniki z lat 1938 i 1939 przybrały już charakter zupełnie inny. Przeważyły tendencje zmierzające ku upolitycznieniu pisma. Pismo przybrało charakter bardziej laicki, ku czemu przyczyniła się między innymi także zmiana na stanowisku redaktora naczelnego, które opuścił twórca czasopisma ks. Stankiewicz. W tych okolicznościach nie dziwi fakt, iż w kolejnych numerach z roku 1939 roku zaczęło pojawiać się coraz więcej notek o ocenzurowaniu artykułów lub informacje o niedopuszczeniu ich do druku. Zanikł też istotny dla zachowania dotychczasowego profilu pisma dział $Z$ życia kościelnego i religijnego. Zwolna zawartość czasopisma przestała korelować z jego tytułem [ChD, 11 (1938); 12 (1939)]. 


\section{Zakończenie}

Czasopismo Chryścijanskaja Dumka, ukazujące się jako periodyk w Polsce międzywojennej w latach 1928-1939, wyłoniła się z pisma „Biełaruskaja Krynica" jako organ prasowy o profilu religijno-społecznym i wychodziła naprzeciw zapotrzebowaniu na treści religijne mniejszości białoruskiej wyznania katolickiego. Pełna analiza zawartości czasopisma i charakterystyka środowiska, które nadawało mu specyficzny charakter forum dyskusyjnego, poruszającego aktualne sprawy o tematyce religijnej, społecznej, rzadziej politycznej oraz ujęcie tej problematyki w rzetelne studium historyczno-bibliograficzne jest przedsięwzięciem, którego owoc trudno byłoby pomieścić na kilkunastu stronicach artykułu. Tematyka ta, tu jednie sygnalizowana, musi poczekać na pełniejsze opracowanie.

Swymi założeniami programowymi Chryścijanskaja Dumka mieściła się w nurcie chrześcijańsko-demokratycznym, reprezentowanym przez Białoruską Chrześcijańską Demokrację, próbującym godzić program religijno-społeczny z hasłami o charakterze narodowym. Pismo tworzone przez białoruską inteligencję katolicką adresowane było zwłaszcza do białoruskich włościan. Popularność, jaką zdobyło czasopismo w środowisku wiejskim, o dużym wszak odsetku analfabetów, dowiodła, iż treści tu prezentowane odpowiadały zapotrzebowaniu tej grupy społecznej na słowo pisane, dające strawę duchową odpowiednio podaną, dostosowaną do poziomu adresatów.

Wbrew deklaracji o apolityczności, pismo było wyrazem dążeń emancypacyjnych mniejszości białoruskiej. Dlatego też, mimo iż do roku 1937 redakcja konsekwentnie podkreślała swą apolityczność, środowisko Chryścijanskiej Dumki postrzegane było przez polskie organa państwowe i władze kościelne jako jeszcze jeden bastion niepodległościowych aspiracji mniejszości białoruskiej. Jako takie czasopismo to, w przekonaniu władz polskich, poprzez budzenie świadomości narodowej Białorusinów, mogło nieść zagrożenie dla integralności wielonarodowościowego państwa. Po rezygnacji ks. A. Stankiewicza, głównego ideologa Białoruskiej Chrześcijańskiej Demokracji i założyciela Chryścijanskiej Dumki, z funkcji redaktora naczelnego, pismo zaczęło stopniowo przybierać charakter organu prasowego o profilu coraz mniej religijnym, bardziej natomiast eksponującym radykalizujący się program polityczny białoruskiej chadecji.

\section{Wykaz skrótów}




\section{Literatura}

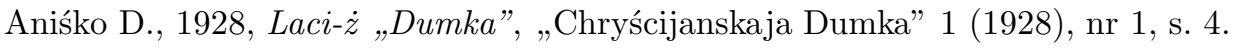
Bukowski J., 2001, Świadkowie wiary, Warszawa.

Catalogus ecclesiarum et cleri archidioecesis Vilnensis pro Anno Domini 1939, 1939, Vilnae.

Choruży W., 1997, Materiały biograficzne, „Białoruskie Zeszyty Historyczne”, 7, s. 158.

Kraśnicki J., 1991, Wiadomości Kościelne Archidiecezji w Białymstoku, StTBł, 9, s. $223-274$.

Kumor B., 1971, Granice metropolii i diecezji polskich (968-1939), ABMK, s. $319-402$.

Listy z wioski, „CHR. D.” i prawastaunyja lubiać, „Chryścijanskaja Dumka” 9 (1936), nr 11, s. 7.

Moroz M., 1993, Z dziejów białoruskiej prasy chadeckiej: „Krynica” - „Biełaruskaja Krynica", [w:] Kresy pótnocno-wschodnie w Drugiej Rzeczypospolitej, Białystok, s. 45-52.

Moroz M., 1997, Działalność Białoruskiego Komitetu Narodowego w Wilnie (19191938), „Białostocczyzna”, 1997, nr 2, s. 48-61.

Moroz M., 2001, „Krynica”. Ideologia i przywódcy białoruskiego katolicyzmu, Białystok.

Rady z Dumki, „Chryścijanskaja Dumka” 1 (1928), nr 1, s. 5.

Stankievič A., 1939, Biełaruski chryścijanski ruch. (Histaryčny narys), Vilnia.

Szot A., 2002, Abp Romuald Jałbrzykowski metropolita wileński, Lublin.

Traczuk J., 1992, Prasa biatoruska w II Rzeczypospolitej (1918-1939), [w:] Studia Polono-Slavica-Orientalia. Acta Litteraria, t. 13, Warszawa, s. 185-373.

U čym budzie abnowa „Chryścijanskaj Dumki”, „Chryścijanskaja Dumka” 11 (1936), nr 12, s. 11.

Z wydawieckaj niwy, „Biełaruskaja Krynica” 1 (1928), nr 16, s. 8.

Ziółkowski A., 1986, Kwartalnik Teologiczny Wileński 1923-1926. Studium historyczno-teologiczne, StTBł, 4, s. 133-164.

Гарошка Л., 1999, Айчеи Адам Станкевіч, [w:] Беларускія рэлігійныя дзеячь ХХ стагоддзя (red. Ю. Гарбінскі), Мінск-Мюнхен, 403-409.

Аніська Д., 1999, [...] Аўтабіяграфія, [w:] Беларускія рэлігійныя дзеячы ХХ стагоддзя (red. Ю. Гарбінскі), Мінск-Мюнхен, s. 258-263.

Гарбінскі Ю., 1999, Жициярыисы (Адам Станкевіч), [w:] Беларускія рэлігійныля дзеячы ХХ стагоддзя, red. Ю. Гарбінскі, Мінск-Мюнхен, s. 183-184.

Гарбінскі Ю., 1999, Жьициярысы (Віктар Шутовіч), [w:] Беларускія рэлігійныля дзеячы ХХ стагоддзя (red. Ю. Гарбінскі), Мінск-Мюнхен, s. 220-221.

Гарбінскі Ю., 1999, Жьичиярысы (Дамінік Аніська), [w:] Беларускія рэлігійньия дзеячы XX стагоддзя (red. Ю. Гарбінскі), Мінск-Мюнхен, s. 7.

Ёрш С., Апошні шлях Адама Станкевіча, „Наша Ніва” z dn. 13.12.1999 r. 
Сіповіч Ч., 1999, Айчеи Язэп Германовіч - жьиьцё і творчасць, [w:] Беларускія рәлігійньяя дзеячьл ХХ стагоддзя (red. Ю. Гарбінскі), Мінск-Мюнхен, s. 289-296.

Сіповіч Ч., 1999, Пралат Пётр Татарыновіч, [w:] Беларускія рэлігійныля дзеячы XX стагоддзя (red. Ю. Гарбінскі), Мінск-Мюнхен, s. 197-198.

Шутовіч Я., 1940, Ксёндз Адам Станкевіч. У 25-ьия ўгодкі свяшчэнства і наивиянальнай дзейнасці, Вільня.

„CHRISTLICHER GEDANKE” (1928-1939)

Z U S A M M E F A S S N G

Die Zeitschrift „Chryścijanskaja Dumka” („Christlicher Gedanke”) existierte in Polen, als periodisch erscheinende Schrift, in den Jahren 1928-1939. Sie ist aus der Zeitschrift „Biełaruskaja Krynica” („Weißrussische Quelle”) hervorgetreten und befriedigte religiöse Bedürfnisse der weißrussischen katholischen Minderheit. "Chryścijanskaja Dumka” hat schon von ihrem Anfang den christlichen und demokratischen Charakter gehabt und, so lange sie existierte, wurde mit dem politischen Verband „Weißrussische Christliche Demokratie” verbunden. Trotz der apolitischen Deklarationen, diese Zeitschrift neigte sich zu den emanzipatorischen Bewegungen der weißrussischen Minderheit hin. Obwohl die Redaktion bis zum Ende des 1937 Jahres konsequent ihren apolitischen Charakter öffentlich deklarierte, wurde sie von der Seite der polnischen Verwaltungsbehörden, sowie von der kirchlichen Verwaltung als Hort der weißrussischen Freiheitsbewegung betrachtet. Als Pfr. Adam Stankiewicz, der Hauptideologe der weißrussischen christlichen Demokratie und der Gründer der Zeitschrift „Chryścijanskaja Dumka” war, auf die Stelle des Chefredakteurs verzichtete, nahm die Zeitschrift den immer weniger religiösen Charakter an. Immer mehr setzte die neue Redaktion ein radikales, politisches Programm der weißrussischen christlichen Demokratie an die erste Stelle. Der Inhalt der „Chryścijanskaja Dumka” entsprach schon nicht mehr ihrem ursprünglichen Programm. 